\title{
Indigenous Well-Being and Development: \\ Connections to Large-Scale Mining \\ and Tourism in the Pacific
}

\author{
Emma Richardson, Emma Hughes, \\ Sharon McLennan, and Litea Meo-Sewabu
}

\section{Community Development and International Capital}

Growth in the South Pacific tourism industry along with rising demand for mineral resources has led to increasing numbers of multinational corporations operating across the Pacific, particularly in the tourism and mining sectors. Multinational hotels and large-scale mining activities are now frequently located near communities with high development demands, and extractive industries are additionally found in very remote and rural locations. Both hotels and mines rely on local communities for access to resources and have an impact on the well-being of these communities through their presence and activities. In contexts where development needs are high, and where governments may fail to provide services, corporations face increasing demands for both philanthropic contributions and long-term service provision (Hughes and Scheyvens 20I6). Thus many businesses now realize that it is in their own interests to look after their host communities, both because this enhances their reputation as an ethical business (Epler Wood and Leray 2005) and because it can decrease the risk of disruption to business operations caused by local communities (Kapelus 2002; Eweje 2007; Kalisch 2002).

In addition, companies operating in the Pacific usually have formal obligations to the landowning communities whose land they lease for resource extraction, tourism, or other purposes. This obligation is significant in relation to discussions of well-being as, typically, local communities do not view their land within the narrow frame of an economic "resource."

The Contemporary Pacific, Volume 3I, Number I, I-34

(C) 2019 by University of Hawai'i Press 
Rather, they see their land as "connected with their long-term interests ... beyond the life of the development, and such interests will typically encompass social, cultural and environmental dimensions-such as providing a connection with ancestors and a place to sustain future generations-in addition to economic interests" (Banks and others 20I6, 25I). The nature of Corporate Community Development and development-oriented Corporate Social Responsibility (CSR) activities in the mining and tourism industries has been discussed in detail elsewhere. ${ }^{\mathrm{I}}$ It is clear that through their development activities corporations have the potential to significantly affect both the development of a region and the well-being of communities in the vicinity of their operations.

Using separate case studies of mining communities in Papua New Guinea and tourism communities in Fiji, we show how indigenous understandings of development and well-being in these communities have increasingly become connected to the presence and dynamics of international capital. Although many landowners and nonlandowners in each location welcome the potential benefits generated by the presence of international companies, a divide remains between the practice of corporate-led development and the local development values that ultimately limits these benefits. This article explores the nature of the connections between well-being, development, and international capital and the implications for private sector-led development in these communities. It first situates the study in the context of the literature on well-being and development before outlining conceptions of well-being that exist in the case-study areas. These ideas are then examined in the context of the presence of international capital, allowing for reflection on the ways in which communities' perceptions of well-being intersect with private-sector development intervention.

\section{Well-Being and Development}

Understanding how well-being or a good life is locally realized is central to advancing the idea of meaningful development. Not only does it create a discursive space for questioning the extent of actions undertaken under the name of "development" (White 20I4) but exploring local understandings of well-being also has the potential to reveal inconsistencies between development initiatives and well-being outcomes, and to make more apparent the connections and disconnections between those involved with promoting "development" and those impacted by it (Copestake 2008). Yet it is only since the I990s that the notion of "human well-being" has 
gained traction in mainstream development discourse in relation to the Global South. In particular, the I990 United Nations Development Programme's Human Development Report acknowledged the significance of human well-being for development, resulting in increased attention to human well-being as a part of development (UNDP 1990). This has been signaled as the "wellbeing turn" in development discourse (Deneulin 20I4, 39). By 20I I, the United Nations had also recognized the "pursuit of happiness" as a fundamental human goal and one that, in addition to well-being, sustainable development, and poverty eradication, should be promoted through more inclusive and equitable forms of economic growth (UNGA 2OII).

Although "well-being" may mean different things to different people, in practice understandings of well-being typically encompass dimensions of happiness (in varying forms), while at the same time including other factors that are more holistic and that are broadly understood to contribute to the makings of a good life (Gough, McGregor, and Camfield 2007). Acknowledging the broader dimensions of well-being is necessary because, as advocated by Edward F Fischer, it is important to "take seriously not only material conditions but also people's desires, aspirations, and imaginations - the hopes, fears, and other subjective factors that drive their engagement with the world" $(2014,5)$. The objective elements of well-being are those material, verifiable, and measurable factors (White 20I6) that sit alongside the intangible, spiritual, psychological, political, sociocultural, and other subjective elements of well-being connected to one's feelings, values, and judgments (Chambers I997; Gasper 2007; White 20I6). The relationship between these dimensions, however, can be complex. For example, Ian Gough, Allister McGregor, and Laura Camfield stressed that well-being is dynamic and continually shifting as a result of the relational interplay between political, economic, cultural, and social aspects of human experience $(2007,5)$.

While in Western culture the process of attaining well-being is often individualized, other cultural and indigenous philosophies commonly understand well-being to be a collective, communal, and relational notion (White 2009,8 ). An appreciation of how well-being experiences and practices manifest at the local level can thus help advance understanding of the construct (Jiménez 2008). In particular, understanding the influence of place is essential to appreciating well-being because "place" provides a form and expression for well-being (Atkinson, Fuller, and Painter 20 I2, 3). Place, of course, includes not only space but also the social and cultural 
values and the social institutions and processes that exist in any place at a particular point of time (McGregor 2007). Recognizing that large multinational corporations influence what it means to lead a good life in host communities is therefore central to the consideration of well-being in locations such as those reported here: tourism-impacted communities in Fiji and mine-impacted communities in Papua New Guinea.

\section{Notions of Well-Being in the Pacific}

Although there is much existing literature on well-being in many locations around the world, and particularly on the concept of buen vivir or "living well" and its relationship to development in Latin America (Radcliffe 20I 2, 24I), there is no single comparable concept in the Pacific Islands. This should not be surprising, given the ethnic and linguistic diversity of the Pacific region, which, according to Elise Huffer and Ropate Qalo, is "one of the most culturally diverse per capita in the world" (2004, 90). However, several Pacific Island concepts describing well-being share similar attributes, including the Kwara'ae philosophy of "the good life" known as gwaumauri'anga in Solomon Islands (Gegeo I998); sautu and bula taucoko in Fiji (Nabobo-Baba 2006, 20I 5; Meo-Sewabu 201 5); and gutpela sindaun in Papua New Guinea (Cox 2006). Each emphasizes a holistic notion of well-being with indigenous knowledge at its foundation. Together these concepts of well-being encompass shared ideas about fulfilling communal obligations, prioritizing collective well-being, and practicing reciprocity-all sustained by local knowledge. Well-being is fulfilled through meeting spiritual, psychological, and physical needs and is underpinned by cultural values such as kin love and kindness, sharing and hospitality, and honesty and humility. The well-being of the individual is often considered inseparable from maintaining healthy relationships and responding to the needs of others. At the same time, discourses of collective well-being in the Pacific include notions of independence, self-sufficiency, and "being able to meet all of one's needs (economic, spiritual, psychological, and so on)" (Gegeo I998, 307). Other comparable concepts can be found elsewhere, for example, linking well-being with harmony and aesthetic values (Mila-Schaaf and Hudson 2009) and with environmental factors and the health of natural resources (McGregor and others 2003).

Huffer and Qalo argued that shared Pacific philosophies allow a comparison between concepts and beliefs in the region: "Because Pacific phi- 
losophies are based on relationships and interconnectedness, fundamental concepts cover a whole range of areas of life, beliefs, and ways of doing and being" (2004, I03). These incorporate related ideas of interdependence and of prioritizing the common good. For example, the concept that practices centered on the good of society are important in order to generate collective well-being is an idea integral to the understanding of different Oceanic terms for wisdom: poto in Tonga, yalomatua in Fiji, and wanawana in Kiribati (Huffer and Qalo 2004, I00). There are also related parallels in accepted ways of living in Fiji that lead to collective well-being or happiness, including "lying straight" (davo donu), which prescribes a life lived with respect for others, for ancestors, for God, and for nature (Tuwere 2002, I30, quoted in Huffer and Qalo 2004, 96). Similarly, for the Kwara'ae in Solomon Islands, gwaumauri'anga or the good life is achieved by showing respect and being respected and by engaging in culturally appropriate and humanitarian activities (Gegeo I998, 299).

The sense of well-being stemming from the pursuit of the collective good is also evident in explorations of cultural differences in the construct of happiness. Although Pacific Island nations do not feature in the major cross-cultural studies of happiness (such as the World Happiness Report [Helliwell, Layard, and Sachs 2012] or the World Database of Happiness [Veenhoven 20I5]), ${ }^{2}$ two studies specifically look at the constructions of happiness in the Pacific-one by Sean Moore, Heather Young-Leslie, and Carrie Lavis (2005) and another by Stephen Pratt, Scott McCabe, and Apisalome Movono (20I6), in Tonga and Fiji, respectively. Each of these lends similar weight to the significance of the collective above the individual. Spanning a combination of subjective and objective domains, these studies found that high levels of satisfaction were reflected in the fulfillment of collective, social, and kinship obligations. For instance, the Fiji study compared levels of happiness in a village located in one of the main tourist areas with those in a traditional village dependent on the subsistence economy. Despite the fact that the subsistence village scored lower on education, health, and living standards, over three-quarters of the residents of that village reported being "deeply happy" compared to less than a quarter of the tourism village (Pratt, McCabe, and Movono 20I6, $3 \mathrm{I}$ ). The higher scores were predominantly reflected in the dimensions of time use, good governance, and community vitality-with a notable emphasis on the role of family. The study concluded that, "although villagers in the non-tourism village may be financially less well off, they claim 
to be socially wealthier as they value kinship, traditions and fewer concerns about money and material wealth" (Pratt, McCabe, and Movono 2016,33).

These examples provide evidence of the holistic notions of well-being and development that exist in the Pacific, encompassing both tangible and intangible dimensions. They also demonstrate that "human well-being" as an accepted universal human goal advanced by the United Nations (UNGA 20II) has long been a collective endeavor in the Pacific Islands. As suggested in the remainder of this article, this has significant consequences for mining and tourism companies seeking to support forms of locallevel community development through or in conjunction with company operations.

\section{Connecting Well-Being and Development in the Pacific}

The extent to which indigenous well-being and development concepts can support meaningful forms of development is an important question in relation to private-sector engagement in local-level development in the Pacific. Indeed, addressing this question may help to mitigate the hegemony of modernity. Des Gasper and Asuncion Lera St Clair have referred to modernity as an idea, a type of society, and a lived experience (2016). As these aspects of modernity reinforce each other, modernity acts to distance us from our "inferior past," creating a "commercialized, industrialized, urbanized, individualized" society that assumes the associated discovery of the "secret to unending advance" (Gasper and St Clair 2016, xviii). The predominance of modernity at an international level can therefore hinder consideration and expression of alternative thought systems and eliminate the space to incorporate alternative ideas into the development initiatives of donors, nongovernmental organizations, and multilateral institutions (Huffer and Qalo 2004, 90, 95).

Huffer and Qalo suggested that Pacific societies already have an understanding of what is needed to achieve well-being, and this understanding is underpinned by culturally embedded philosophies and values that emphasize the collective good (2004). A number of narrative examples of the importance of local systems and processes in realizing well-being through community development provide illustrations of this. Litea MeoSewabu and Wheturangi Walsh-Tapiata illustrated how external development processes have undermined local well-being in Fiji by creating increased dependence on external resources and leading to the loss of local 
skills (20I2). Conversely, they showed that initiatives that build on existing community processes and that take into account practices of working collectively (solesolevaki) and prioritizing the collective good-for example, communal savings initiatives-are more likely to contribute to well-being. In each of these examples, the use of indigenous knowledge in practice is central to the expression of self-sufficiency and agency in locally designed and implemented initiatives aiming to increase well-being in the community. For instance, Michael Spann has observed how agricultural practices in Malaita, Solomon Islands, are being improved through "embedding them in local specifics" to create practical development alternatives emphasizing "social values of exchange and local adaptations" $(2018,35,57)$.

Too often, development principles that are introduced in the Pacific, such as human rights and good governance, lack meaning because they stand disconnected from established Pacific values relating to social justice and welfare for all (Huffer and Qalo 2004, 94). David W Gegeo, for example, asserted that development from the outside is often a form of disguised modernization. He noted that in traditional Kwara'ae beliefs, "Anything done as liakwaimausuli'anga 'imitation' of something else rather than talasau or talafuli ana ngwae 'having its source in the doer,' is 'iri lalifu, that is, 'lacks root and dignity,' and is destined to fail" (I998, 297). Furthermore, he suggested that participating in others' external projects can lead to de-skilling and a loss of dignity; therefore, he advocated for the centralization of indigenous and local knowledge at the core of development models in the Global South (Gegeo I998, 289). Similarly, Tarcisius Kabutaulaka used the term "alter-natives" to describe ways in which Melanesians are mobilizing through local political and economic processes to reclaim and redefine local representations and identities (20I5).

In "Our Sea of Islands," Epeli Hau'ofa argued compellingly for development to focus on the grassroots practices of ordinary people and local interpretations of community development, which are often overlooked, misinterpreted, or ignored by donors and consultants (I994, I48). Put differently, when introduced concepts and development projects are grounded in indigenous autonomy, and when they recognize that the "symbiotic relationship between the doer and the project means that a project becomes part of one's life," then external forms of development intervention may still be of use and considered locally meaningful (Gegeo I998, 308). With this in mind, this article presents two case studies from the Pacific, focusing on local understandings of well-being and develop- 
ment and how these intersect with the presence of international capital in each locality.

\section{Case Studies}

The case studies explored in this article are part of a larger program of research examining Corporate Community Development activities in the Pacific (see Banks and others 20I6; Scheyvens, Banks, and Hughes 20I6). Given that the private sector has been recognized to hold an integral role in the promotion of development (UNGA 20I 5), the research program was premised on a need for more evidence of how corporations engage in community development, in order to better understand both the potential and risks associated with this. Mining and tourism were selected for investigation as key industries in the Pacific. In Papua New Guinea, resource extraction and exploitation dominate the country's export-oriented economy. Papua New Guinea is one of the world's top twenty copper and gold producers, and in 20I4 the export of minerals constituted 84.I 8 percent of total national export value (Ernst \& Young Australia 20I7, 6, 26). In Fiji, tourism is a key growth area: arrivals exceeded 800,000 for the first time in 2017 and are predicted to reach up to I.2 million by 2027 , with tourism and tourism-related employment and spending contributing 40.4 percent of gross domestic product in 2016 (World Travel and Tourism Council 20I7, I). Even though these industries remain categorically different from each other in their nature, scale, and impacts, both large-scale tourism and mining operations are commonly rationalized and premised on their potential to contribute to local development (Telfer and Sharpley 2008; World Bank 2009, 2013; Weber-Fahr 2002). Thus, the central question driving the research program was, "Do the community development initiatives of mining and tourism corporations operating in the Pacific bring about locally meaningful development?"3

The case studies outlined here are drawn from two different $\mathrm{PhD}$ research projects within this research program. While the respective $\mathrm{PhD}$ projects progressed independently and were not intended to be directly comparative in nature, when read in conjunction, they help cultivate a more comprehensive understanding of the role of corporate support for community development in the Pacific. Case Study One explores the notions of wellbeing and development as they relate to gutpela sindaun in the two island communities of Lihir and Simberi, located off the northeast coast of New Ireland Province, Papua New Guinea. Both of these communities have been 
impacted by large-scale open-pit gold mining activity undertaken by two different mining companies. Lihir Island (also known as Niolam Island) is the largest island of the Lihir group, which consists of Niolam, Masahet, Mahur, and Mali islands. Lihir's gold deposit is thought to be one of the largest in the world, and in 20I 5 the Lihir gold mine produced 688,7I4 ounces of gold (Newcrest 20I 5). The somewhat smaller Simberi gold mine is reported to have been running at its target production rate of 100,000 ounces of gold per year since March 2015 (St Barbara Limited 2015, ii). Located approximately sixty kilometers northwest of Lihir, Simberi is the northernmost island of the Tabar group, which encompasses the islands of Simberi, Tatau, and Big Tabar. Case Study Two explores the idea of bula taucoko (well-being) in villages in two tourist locations in Fiji, one on the Coral Coast on the south shore of the island of Viti Levu and the other adjacent to Denarau Island, on Viti Levu's west coast. The tourist destination of Denarau Island houses nine internationally owned resorts, which receive 50 percent of tourist arrivals to Fiji (Bernard and Cook 2015). The Coral Coast is the second-largest tourist destination in Fiji, accounting for I 8 percent of the country's visitors (Movono, Pratt, and Harrison 20I 5 , I03). Landowners in the case study villages of Narewa and Nakavu in Nadi, near Denarau, and Cuvu on the Coral Coast receive lease money from the hotels along with benefits such as preferential employment and business opportunities.

In each of the four research communities, researchers used a combination of semi-structured interviews and group discussions with community members, including mining/resort lease-area landowners and nonlandowners, to identify the themes central to this discussion. In Fiji, a total of thirty interviews and group discussions with community members were undertaken across a four-month period in 2014. Research findings locate the discussion of well-being within an understanding of traditional iTaukei (Indigenous Fijian) culture and values, which in turn shape village priorities for development. Villagers were asked to describe what well-being meant to them, including physical, spiritual, emotional, and economic aspects of well-being, or how they would describe "a good life." While well-being in the Fijian context has elsewhere been defined as "sautu" (Nabobo-Baba 2006), participants in this study all used the term "bula taucoko" to describe well-being. The same term is also used by Meo-Sewabu to describe well-being (2015), and it is the definition used in this article. In Papua New Guinea, research was also undertaken in 2014 across a four-month period and included more than sixty interviews 
as well as group discussions. Here, an attempt to understand the notion of locally meaningful development was informed by the research participants' ideas and values related to the concept of "community development" and the idea of "gutpela sindaun," which is the Tok Pisin phrase used in Papua New Guinea to signify the existence of a good quality of life (Jacka 2007).

Across the case study areas, localized understandings of meaningful development encompass both tangible and intangible components, reflect the holistic nature of well-being, and reiterate the importance of the collective good. As discussed in the next sections, they also commonly echo the presence and impact of the private sector, emphasize community expectations for development-based forms of corporate reciprocity, and characteristically convey a hope for more equitable forms of company-derived benefit distribution.

\section{Case Study One: Gutpela Sindaun and Community Development in New Ireland Province, Papua New Guinea}

\section{Understanding Gutpela Sindaun}

Gutpela sindaun literally means "sitting down well" and implies the existence of a good life (Stewart and Strathern 2000) and therefore a good quality of life (Jacka 2007). It is a socially and politically significant phrase in Papua New Guinea, often used to describe "what it means to be an effective community or society, as those who 'sit down well' are able to be still and stable in the company of others; it implies a good state of being" (Gillespie 20I3, I8I). References in theological literature further suggest that gutpela sindaun signals the abundant life for which Papua New Guineans strive (Kero I998; Wani 2010). According to Gibson Wani, this abundant life is a life of "harmony, peace, unity, social justice, wholeness, restoration, freedom, security, plenitude, and release from oppression," which only becomes possible "when things are right" (2010, 89). When things are right, the material indications of gutpela sindaun for a community might include, for example, the absence of sickness, gardens producing ample food, and the existence of healthy livestock (Kero I998, 60). Gutpela sindaun has therefore been described as denoting being "healthy," encompassing a collective understanding of health that includes "security, health, wealth, growth, prestige, good relationships, meaning, etc." (Orathinkal and Vansteenwegen 2004, I49). 
On Simberi and Lihir, there is significant consistency among local interpretations of gutpela sindaun. Not only is it understood to reference healthy living, happiness, and physical health within the family and the community at the present, but it is also largely understood as being an expression of community health over time. It is a term used to refer to internal community well-being as well as peaceful living by the family and is also understood by many to signify an improved state of being - a state that was commonly hoped would flow from mining. As one interviewee put it:

Gutpela sindaun is something that should be part of community development. It means to help the young people to grow up and know [the difference] between good things and bad things. Giving youth opportunities to take part in mining, to make then know the good things and bad things about development.... When the Company finish, then they [the youth] should know what next. But now I don't see anything like this. (Male landowner outside the mining lease area, Lihir Island, PNG)

Within the research context, gutpela sindaun is a term that, by default, becomes linked to development as well as to mining and the uncertainty of the post-mining future for each Island community.

\section{Well-Being as Gutpela Sindaun and Development}

Community development is development that must result in gutpela sindaun. (Male lease-area landowner, Lihir Island, PNG)

While development is an introduced concept in Papua New Guinea, gutpela sindaun has come to be closely related to, and even conflated with, understandings of community development. Similar to gutpela sindaun, community development is associated with the idea of better living and healthy relationships. However, although research participants often described the qualitative scope of gutpela sindaun, it was the material dimension of community development and its connection to mining operations that was most commonly emphasized. The material aspects of community development identified include improved housing, health, education, water supply, transport infrastructure, and, more broadly, the infrastructure that would support all of these development goals. While some landowners also considered self-reliance, community-level empowerment, and the associated development of knowledge to be important aspects of community development, most emphasized the significance of social and infrastructural development that could be of benefit to the wider community as a whole. 
Understandings of gutpela sindaun and community development thus highlight the relational dynamic between well-being and development within the case study context. A connection exists between experiences of gutpela sindaun, aspirations for local-level development, and the expectation of development benefits stemming from mining. Gutpela sindaun provides a holistic framing for community development in which a collective sense of improved health and an enhanced quality of life are the foci. Accordingly, the material components of community development that are significant at the local level—such as housing, health care, road building, and general infrastructural development—dissolve into people's aspirations for gutpela sindaun. In other words, community development can generally be understood as being a form of development that must necessarily result in gutpela sindaun.

\section{Well-Being, Development, and Mining}

Locally significant well-being and development values such as reciprocity can be understood to be an expression of place that reflects the significance of mining operations for landowners. For example, well-being and development aspirations for improved community health, road building, housing development, electricity, and water supply and reticulation connect back to the benefits that landowners had hoped (and still may hope) to derive from mining operations. Aspirations also commonly connect to the content of mining community development and benefit-sharing agreements negotiated with customary landowners on each island, as well as the heightened landowner expectations that arose as a consequence of these agreements and as a result of the arrival of mining more generally. Kastom and the associated importance of the values of reciprocity and redress for local communities further reinforce the association between landowners' understandings of well-being and expectations of mining operations. ${ }^{4}$ The connection between local understandings of gutpela sindaun and community expectations on the one hand and hopes that mining operations will act as a catalyst for development on the other accordingly reflects the significance of mining operations to landowners as well as the significance of the adverse social and environmental impacts of large-scale mining.

While people have clear aspirations for well-being and development, aspirations nevertheless often fail to align with what people anticipate for their future. A range of community well-being concerns consequently exist on Simberi and Lihir, and just as community well-being aspirations reflect 
the impact of mining, so too do these concerns. These concerns are primarily based on unease over the general lack of island-wide development, worry about the potential constraints of future post-mining livelihood opportunities for those who have lost their land to mining, and anxiety over the consequences and extent of mining-derived environmental damage, as expressed by one interviewee:

Community development is what the community must have. The damage has been done, and now community development must occur and bring about change because of these mining operations. (Male landowner outside the mining lease area, Simberi Island, PNG)

On Simberi Island, for example, experiences of environmental damage dominate well-being concerns across the island, and interviewees often stressed the significance of environmental well-being in relation to human well-being and the need for company-initiated community development. Numerous landowners in this study drew on the pre-mining past as a reference for visualizing a utopian model for the post-mining future, expressing the desire for an environmental future like it was before mining, "like it was in the first place," with its mountains and rivers intact and "as God created it." Concern over the loss of natural resources (including areas of land and sea) as a consequence of mining also underlies well-being and development concerns held by lease-area landowners on Lihir Island. With the availability of environmental resources being connected to quality of life by landowners, here a loss of community-level gutpela sindaun has been attributed to the loss of natural resources.

\section{Case Study Two: Bula Taucoko in Fiji}

\section{Understanding Bula Taucoko}

The concept of well-being among indigenous Fijians, defined as na bula taucoko or taucoko na bula, is underpinned by the ethos of sharing and helping. One villager explained the core Fijian value of "sharing and caring" as "veivukei" and said that when people talk about doing things "from the good heart" or "with a big heart," this is "yalo vinaka." This is about giving all your heart to help: "We can't walk past a house when they need something. We are all related. When there's no salt, we go to the next house and kerekere [borrow]." Bula taucoko is described as a combination of physical, spiritual, and emotional well-being or completeness: taucoko translates literally as "completeness" and "bula" as life. Another 
villager described the state of bula taucoko as "everything is ok," that is, all essential needs are met. Sitting at her kitchen table, she used a new jar of chutney she had just purchased to illustrate: the jar is full right to the top, nothing is missing. At a village level, she noted, this involves being able to meet communal needs:

We can meet all the village needs so everything will be taucoko, everything will be "set." Everyone has a good house with a toilet, bathroom, we have a community hall in the village. Everyone stays in a healthy place, a healthy environment. And life will be taucoko. (Female landowner, Cuvu village, Fiji)

The idea of bula taucoko is also connected to agency and the ability to make decisions at both an individual and at a collective level. As described by one man:

A complete life. A house, food, a job, the kids at school. A feeling of satisfaction that you have everything. There's no asking from the government or anyone else. We can depend on ourselves. (Male landowner, community leader, Narewa village, Fiji)

Two examples illustrate this idea of agency and self-sufficiency. In Cuvu village, the current source of water is a government reservoir, but village elders explained that water bills were increasingly high. A drilling company had carried out a scoping investigation for the village and identified two water basins. If the village can fund the drilling of boreholes, they will then have control of their own water. The capacity to become selfsufficient and provide their own supply of water for the village was identified as contributing to bula taucoko. The second example is from Narewa village, which floods every rainy season, making sections of the village impassable. This is a particular problem for the school children, who then have to walk home along the main road rather than coming directly through the village. Through a soli (fund-raising), the village together was able to raise $\mathrm{F} \$ 30,000$ toward the construction of footpaths; however, the construction company quoted $\mathrm{F} \$ \mathrm{I} 00,000$ to complete the work (in 20I4, $\mathrm{F} \$$ I, 000 was the equivalent of about US $\$ 520)$. The village head explained that they decided to complete the construction work themselves. The men laid the footpaths while the women prepared the food. Such activities were also identified as contributing to bula taucoko. The village head went on to explain what this means:

It has to come from within-accept what we have, work with the things that we have and look for resources, assistance readily available. It doesn't have 
to be government-it can be a neighbor, church. In the village we have a very strong foundation of getting that done by working together. We work together, use our land and resources and at the same time enjoy life! (Male landowner, community leader, Narewa village, Fiji)

Participants also described the link between sautu and bula taucoko, defining sautu as a completeness of needs, or even abundance, particularly with regard to natural resources. One discussion identified this abundance as the foundation of well-being or bula taucoko:

A: Sautu is peaceful, complete. You have a garden and everything is there, you just go and pull up the cassava, the bele [Fijian spinach] ...

J: When we have lots of food and the soil bears lots of food we say it is "sautu."

A: And that becomes taucoko. From the sautu, everything is there, you [achieve] taucoko ni bula. So life will be ok. (Focus group, nonlandowners)

\section{Well-Being and Community Development}

Fiji village priorities for community development are embedded in the vanua values of sharing, reciprocity, and respect for customary obligations and kinship relationships, all of which are closely connected to the specifics of place. The vanua can be translated as "a people, their chief, their defined territory, their waterways or fishing grounds, their environment, their spirituality, their history, their epistemology and culture" (Nabobo-Baba 2006, I 55). It is of physical, social, and spiritual significance, encompassing the physical area, social systems, and cultural values. Priorities parallel the components of bula taucoko, including material needs, such as the ability to sustain the village by means of income and access to resources, alongside intangible elements, such as the ability to fulfill communal and customary obligations and practice reciprocity.

Material needs include having the means to provide for the village as a whole, achieved through access to plantations, fishing grounds, and perhaps a piggery along with sources of employment to ensure that financial needs are also covered. Provision of services and facilities includes building concrete houses-identified as a priority for villages as they are more resistant to cyclones and flooding; having sufficient housing to avoid overcrowding; and furnishing each house with a bathroom and water supply. Priorities also include ensuring access to education for the younger generation to enable them to secure employment. This in turn supports the ability of the village to be self-sufficient and exercise self-determination. 
Intangible priorities include having the means to practice reciprocity and help others in the village. This encompasses meeting cultural and religious obligations, including maintaining churches as well as burial grounds and paying respect to ancestors. Priorities also involve ensuring that there is a place to meet (for example, a community hall); being in a position to contribute to family and village requests for assistance; and participating in village development projects. The concept of well-being and a focus on meeting collective needs connects the tangible and intangible priorities, underpinned by vanua values. These priorities are expressed in terms of meeting vanua values, even when in practice they may not necessarily be realized in this way.

\section{Well-Being, Development, and Tourism}

In both Fiji locations, the tourism industry has had a significant impact on communities. Within the landowner villages in each location, more than half of the adults had at some point been employed by one of the hotels, either directly (in a range of roles from housekeeping to management) or indirectly (for example, as a taxi driver or babysitter). The income from employment, lease money, and provision of entertainment and village tours plays an important role in fulfilling the village priorities identified in the previous section.

Village projects are resourced and implemented through communal contributions. Each village or mataqali (subclan) holds an annual soli at which everyone gathers together, along with family and friends from outside the village as well as village members who have moved away. Customary protocols observed at community gatherings include prayer and the provision of food, kava, and entertainment. A donation is requested from each individual, with the amount given recorded in keeping with reciprocity protocols. Projects are undertaken collectively. Referred to as solesolevaki (Meo-Sewabu and Walsh-Tapiata 20I2), this means to work together to achieve a purpose. In this way, community halls are built, footpaths laid, churches painted, and roofs thatched. In tourist villages, lease money and employment enable more significant financial contributions to be made; the resulting size and scope of village projects are therefore intimately connected to the corporations leasing village land.

International resorts are seen to provide a resource to support villagelevel development, and there is a clear expectation that hotel leases will result in greater capacity to realize community development plans. Participants in the study articulated expectations for the presence of tourism 
to result in improved material development for the village as a whole. Yet increased income in landowning villages can also lead to discord as villagers allocate their income to household needs rather than community development. As one villager expressed it:

The trustees [of the lease money] ask if we can put the lease money in the bank for development. But now people say they want the money. Some are not working-they need it for sugar, flour, tea. (Female landowner and community leader, Nadi, Fiji)

Furthermore, the inequality in prospects for achieving material development by landowner and nonlandowner villages can be seen in the goals they identify. In landowner villages, objectives include the construction of concrete houses, while neighboring nonlandowner villages might aim just to ensure that each house has a flush toilet. Villages in receipt of lease money are able to use funds to carry out more ambitious community-development projects over a short term, for example, opening a dispensary or village resource center with study space and sewing facilities. In comparison, a neighboring nonlandowner village took thirty years to raise sufficient funds to complete their community hall. It is evident that in landowning villages, priorities for development and achieving bula taucoko are closely connected to the possibilities offered by tourism. Importantly, however, hopes for tourism to contribute to community well-being were also expressed in nonlandowning villages near the hotels. Based on the indigenous values of reciprocity and prioritizing the collective good, the presence of international hotels on indigenous-owned land is expected locally to generate benefits for the whole community.

Hotels do also generate wider benefits, for example, through Corporate Social Responsibility projects that allocate resources to the local school or kindergarten serving a number of villages. However, village development initiatives such as constructing a community hall are determined wholly through village processes and are premised on vanua values, whereas projects determined by the hotels are carried out independently of village development processes. A CSR focus on provision of services can also overlook the importance of the intangible elements integral to community well-being, such as reciprocity, and result in a disconnection between corporate and community approaches to development. While community needs do include a focus on material demands for improved education and health care, this is an incomplete picture. Community goals also include 
the ability to satisfy collective needs (rather than individual needs), support practices of sharing and gathering, sustain cultural practices, meet cultural obligations, and enable group self-sufficiency. Solesolevaki means the practice of jointly working together to achieve a purpose; the essence of well-being is rooted in this coming together to attain well-being for the collective. Gaining an income and achieving good education and health are therefore not ends in themselves but serve as means toward achieving bula taucoko for the whole community.

\section{Well-Being, Development, and International Capital}

The case studies discussed here demonstrate the confluence of development issues in both countries, despite the wide variance in the nature of the industries and the levels of development in each of the communities. The presence of multinational corporations has permanently altered the landscape in each community, affecting access to and use of land and having impacts on the natural environment and natural resource availability. At the same time, both mining and tourism offer possibilities for increased income generation and raise expectations for improved infrastructure and tangible improvements in livelihoods.

Across the case studies, there are significant similarities in how wellbeing is conceptualized and how it is understood in the context of international capital. As illustrated in table $\mathrm{I}$, the material and intangible dimensions of well-being connect to and are partially informed by the presence of tourism and mining. Thus the existence of mining and tourism is infused with locally held well-being values. This, in turn, illustrates how tourism and mining operations exist to shape aspects of place, which provide form and expression to understandings of well-being (see Atkinson, Fuller, and Painter 20I2; McGregor 2007). While there are differences in understandings of well-being in the two countries, material and intangible components of both focus on the well-being of the collective. As contextualized in the case study narratives above, forms of development can generally be deemed to be locally meaningful if they deliver both tangible and intangible benefits, that is, provide material support that is culturally embedded and also advance living standards for the community as a whole.

We argue that there is a need to focus on such community conceptions of well-being and development in the context of multinational capi- 
Table I Connecting Development, Well-Being, and International Capital in the Pacific

\begin{tabular}{lll}
$\begin{array}{l}\text { Dimension } \\
\text { of Well-Being }\end{array}$ & $\begin{array}{l}\text { Mining Case Study Context } \\
\text { (Papua New Guinea) }\end{array}$ & $\begin{array}{l}\text { Tourism Case Study } \\
\text { Context (Fiji) }\end{array}$ \\
\hline
\end{tabular}

Material/Tangible

Longer-term human wellbeing and livelihood concerns encompass economic considerations connected to mining. The distribution of economic mining benefits, and the access to these benefits, can support both the realization of familyand community-level gutpela sindaun and local-level (community) development.

Other tangible components of well-being that are linked to mining include potential benefits to community infrastructure such as housing, roads, and electricity supply.

Intangible (Spiritual/ Psychological/ Social/Cultural)
Healthy living and peace within the family and community inform experiences of gutpela sindaun. Healthy living includes psychological well-being, which connects to environmental and human security considerations relevant to human survival and community subsistence. The existence of peace and harmony in the community underpins local understandings of the good life. As attributes of gutpela sindaun, these social dimensions of well-being interconnect with the material and psychological dimensions of well-being and development.

Although the financial benefits from mining (including lease money, compensation payments, and wages) can support livelihoods and flow back into kastom, they can also be a source of tension in the community and disrupt and inhibit the manifestation of gutpela sindaun.
Secure and sustainable livelihoods are generated through gaining employment in the hotels and through land-lease money. This allows the development of housing and other community development projects for the village in addition to meeting customary financial obligations, which are all part of bula taucoko.

Other tangible components of well-being linked to tourism include support for education and health, such as infrastructure and resources for kindergartens, schools, and hospitals.

Practicing a peaceful life in the community and maintaining religious practices and customary obligations are core elements of bula taucoko. Social and cultural well-being results from living harmoniously in the village according to the vanua values and also leads to spiritual and psychological well-being for the community as a whole. Respecting vanua values includes practicing reciprocity and working together (solesolevaki) to meet customary obligations, in this way connecting with the economic or material dimension of wellbeing.

The financial benefits derived from tourism, including lease money and wages, are used to contribute to meeting customary obligations but can also undermine collective ways of working. 
tal in order to establish a more nuanced appreciation of the intersections between these ideas. Traditionally, well-being in many Pacific cultures is a collective concept. It is often viewed as the ability to provide for the benefit of everyone in that community rather than for individuals. Social, cultural, and spiritual well-being is cultivated through the coexistence of formal and informal systems that meet indigenous goals of well-being for the whole. While such a collective, egalitarian focus clearly differs from a Western perspective, it is consistent with the understanding in Pacific communities that there is a need to share wealth to provide for the collective good.

Yet in the current context there can sometimes be more to gain, economically and otherwise, by focusing on individual benefits, particularly in the context of large-scale development. Within the case study areas, the arrival of multinational corporations has led to heightened expectations for opportunities to fulfill community aspirations for development but has also increased the adoption of more individualistic practices, resulting in tensions at the community level. In Fiji, for example, there is evidence that customary decision-making processes are now increasingly influenced by individual priorities. Although until 20I I the division of tourism lease money was the responsibility of chiefs, with a percentage set aside for heads of mataqali and yavusa (clan) based on customary hierarchy, the Equal Rent Distribution Policy implemented by the Fiji government in 2014 means that lease money is now shared equally between all registered landowners. While the mataqali still retain the capacity to agree on retaining a portion of the money for communal development projects, some members of the community are beginning to resist this and exert their right to the money for individual needs. Similarly, in Papua New Guinea, the egalitarian ideal of unity and the influence of individual autonomy are continually being negotiated (Barker 2007). As observed by Nicholas Bainton on Lihir Island (2009), traditional notions of egalitarianism, reciprocity, and obligation are changing as more individualistic forms of behavior influence the sharing of mining-derived benefits. While the economic benefits of large-scale mining activity have the potential to be extensively drawn on through kinship networks, Bainton has found that landowners are instead purposefully circumscribing their social networks in an attempt to limit the distribution of mining benefits across the island community (Bainton 2009, 20I0).

It is also apparent that the allocation and distribution of benefits from both mining and tourism is essentially a political process, informing, in 
part, who is included and excluded from the receipt of development benefits. The landowner well-being and development concerns identified above link community well-being-or its absence-to the inclusion or exclusion of company benefits. For example, the community development opportunities offered by increased income levels in landowning villages in Fiji, or by the provision of compensation for mine-affected villages in Papua New Guinea, create further disparities in income levels and the extent of community development opportunities that exist across lease and nonlease landowner areas. Thus, the existence of multinational capital offers opportunities to advance community aspirations for well-being and development, but at the same time it can undermine the collective foundation of achieving well-being for the whole. Issues of transparency and accountability between the company and community, and within the community, therefore surface as important to local well-being and development considerations. In this sense, multinational activity such as large-scale mining and tourism operations can be seen as both the potential solution to community development problems and the source of potentially unforeseen development issues.

\section{Development Disjunctures}

In both cases, there are clear instances of disjunctures between community development expectations and reality. Both landowning and nonlandowning communities expressed dissatisfaction with the material development resulting from the presence of the hotels and mines. Interviewees from Fiji and Papua New Guinea, respectively, noted such attitudes:

You look at the hotels-how many, 8? - and this [village] should be in top living conditions, better houses, a tar-sealed road. It's not happening. You have to ask, why is that? We can see Denarau from here, the lights. It's like it is Ioo miles away. We are talking about development, the conditions here. (Male landowner, Nadi, Fiji)

The first gold production was in 2008 , it's now over 6 years... This is a small island, the Simberi population is less than I,000, and by now we should have permanent houses, a better toilet system and water supply system. That's what I'm referring to as development. (Male lease-area landowner, Simberi Island, PNG)

At the same time, there is also the expectation that the presence of the companies will meet local perceptions of well-being beyond a material 
focus in landowning areas, that is, that the company's presence should lead to improved quality of life for the collective. In the PNG case study communities, the idea of community development goes beyond the simplistic notion of linear forms of societal advancement. Landowners view quality of life "advancement" as necessarily being culturally embedded and as being supportive of gutpela sindaun. It must also support the advancement of living standards beyond the elite minority, to encompass the island community as a majority. Similarly, within the Fijian case study communities, due to the village social structure that supports all members of the community, the economic benefits from tourism are seen as serving a defined purpose: to meet the basic needs of the village as a whole, rather than be used to accumulate individual wealth. As iTaukei communities seek to live vakavanua (according to the way of the land), this is also what frames and permeates daily life, longer-term goals, and future aspirations. Fulfilling community development goals and achieving well-being or bula taucoko results from living in this way.

A further disjuncture can be identified between the development values as held by landowners and the scope of mining and tourism company community development support. This disjuncture is directly linked to the social importance of the good of the collective and is expressed by landowners in the case study communities as the expectation for reciprocity. For example, the dynamic connection that exists between landowner understandings of well-being, development, and mining in PNG case study communities, reflects, in part, the need for corporate-community reciprocity and, in varying instances, the need for socio-environmental remediation. As one interviewee stated:

It was a Clan understanding of reciprocity, solidified through Kastom, that enabled the mine to come, because the community expected to receive in return. (Male lease-area landowner, Lihir Island, PNG)

On Lihir and Simberi, in both lease area and non-lease areas, mining companies are deemed by landowners to hold a central role in the fulfillment of local landowner development aspirations. Yet due to the disjuncture between the desires for development and the reality in which people live, hope for development remains marred by frustration and disappointment with respect to the current forms of mining companycommunity development initiatives and the limited scope of the tangible development benefits that eventuate from them. In certain instances, the 
extent of environmental damage caused by large-scale mining operations further reinforces the desire for corporate reciprocity in the form of community development intervention and community well-being and development support.

Reflecting on the core value of reciprocity to Fijian understandings of well-being can help to explain the difference in development values between villages and tourism companies. The expectation for reciprocity is evident in the following expression of Fijian expectations of hotels:

We are part of the hotel. We work for the hotel, the tourists come here. The GM [General Manager] should visit the village, come down and hear from the community. (Male nonlandowners, Coral Coast, Fiji)

However, it was apparent that the values of reciprocity and collectivity demonstrated through community-led projects are not visible in corporate-led community development projects in Fiji. There is a disconnection between corporate-led development projects and the multifaceted and largely self-sufficient community development processes, which aim to elevate community well-being for the whole. Community-led processes not only result in community halls, footpaths, kindergartens, village events, and ongoing village maintenance but also support community well-being through fostering communal values of reciprocity and obligation. Thus, it is critical that companies appreciate the collective and self-sufficient imperative underlying the state of well-being in order to support community priorities and goals in a sustainable way. ${ }^{5}$

Significant differences between the two contexts are also evident. In Papua New Guinea, the focus on compensation for lost land and damage to the environment, together with formal community development and benefit-sharing agreements established between mining companies and host communities, results in an emphasis on the responsibility of companies to intervene to deliver development and to compensate for the damage caused. Expectations for community development exist alongside legal requirements for compensation for the loss of land or environmental damage. Compensation benefits and development benefits are therefore considered to be theoretically separate but become practically intertwined matters, as reported by one interviewee:

At first we thought that the benefits that the mine were offering us, including relocation benefits, would provide us with an alternative form of gutpela 
sindaun, but later we realized that these benefits were not enough. (Female lease-area landowner, Lihir Island, PNG)

In contrast, in Fiji there is a greater sense of entitlement to a share of the resources from the leased land in order for communities to be able to determine their own development pathways. In Fiji, rather than seek an increase in hotel-driven assistance, some community members expressed a preference for access to a larger share of the financial resources. Community leaders in Narewa village voiced a desire for greater income from lease payments in order to advance community development according to their own priorities:

Our main concern is a better income [from lease money]. Once you have an income from your resource, you'll have better development. (Male elder and landowner, Narewa village, Fiji)

In both contexts, it is important to acknowledge the ambivalences and uncertainties that underlie discussions of community well-being in the context of the presence of international capital in the Pacific. As communities are not static or homogenous, inflating the idea of a single community can be problematic for companies seeking to promote local forms of well-being. In tourism communities in Fiji, for example, hierarchies of decision making within communities and differential access to resources and opportunities between landowning and nonlandowning villages have the ability to create or exacerbate tensions at a broader community level (Hughes 20I6). Tourism operations therefore inevitably affect decisionmaking at the level of the mataqali, village, and district, fueling divisions between as well as within villages, being referred to by a former project officer at one nongovernmental organization as "conflicts within conflicts." Likewise, in Papua New Guinea, when mining companies treat dynamic and ever-changing social groups as fixed entities, they fail to recognize the complexity of social relationships and thereby increase the chance of project failure (Jacka 20I 5 ).

Importantly, within both case study communities, there appears to be no clearly delineated community opposition to either mining or tourism; in fact, the industries are generally welcomed as opportunities to advance community development and fulfill community expectations of well-being. But, while disenchantment characterizes the perceptions of all four communities, hope remains that companies will begin to govern their operations in a manner that prioritizes local aspirations for well-being and development. 


\section{Conclusion: Opportunities for the Promotion of Meaningful Development}

Although multinational operations have the potential to benefit communities in the Pacific, they can also disrupt local values and principles and lead to more individualized practices, ultimately having negative impacts on community well-being. This article illustrates two specific cases of this, highlighting the disjunctures between indigenous perceptions of the good life in Fiji and Papua New Guinea and experiences of "development" associated with large-scale mining and tourism operations. Yet the gap between the aspirations for community well-being and development and their fulfillment is also the space where opportunities exist to advance meaningful forms of development. How can this be achieved? We believe that if multinational companies genuinely seek to support locally meaningful forms of human development, they must find points of connection with indigenous values of well-being and development.

Further, locally premised indigenous values and relations can provide a vital form of protection for communities, as Steven Ratuva noted: "Sociocultural relations specific to semi-subsistence economies such as those in the small Pacific Island states are still important in providing the social protection mechanisms that are necessary in responding to social risks" (2010, 40).

Ratuva made the point that those within Pacific Island communities who are excluded from the benefits of economic development continue to rely on traditional relationships that act to "protect people from conditions that are beyond their control" (2010,43). Related to our argument, Ratuva emphasized that reliance on traditional social networks is not necessarily inconsistent with the desire for economic development, but rather, that they can act as a complementary set of social protection measures to support communities. Connecting indigenous well-being values with private sector-led development initiatives therefore exists as an opportunity for all multinational companies seeking to support meaningful forms of development within the Pacific.

We argue that recognizing the value of the collective good to indigenous communities must be a key component of any form of community development intervention. After all, at the core of notions of collective wellbeing in the Pacific is the ability to work together for the common good, to share burdens and responsibilities as well as benefits. The disruption of collective well-being can both increase the level of individual uncertainty 
and decrease the level of collective security for those excluded from the benefits of international capital. Consequently, embedding forms of corporate development intervention within local culture in a manner that recognizes intangible well-being values, such as the value of reciprocity, can support people to navigate the dynamic pressures present within their communities.

In the context of large-scale mining and tourism operations, where economic, cultural, and environmental change can alter and has altered the social fabric of indigenous communities, we believe that the forms of external community development support with the greatest potential are those with an understanding of local development values. This key finding is also likely to have relevance for relationships between international capital and communities elsewhere, particularly where corporations are located on indigenous lands and contributions to community development are expected by communities and company stakeholders. If we are correct, the success of externally driven corporate community development hinges on its ability to bridge corporate development practices and indigenous development values in order to lead to locally meaningful human development outcomes.

Our Research was Supported by funding from the Royal Society of New Zealand. Thanks go to the National Research Institute, Papua New Guinea, and to the Ministry of Education, National Heritage, Culture and Arts, Fiji, as well as to anonymous reviewers for their insightful comments.

\section{Notes}

I Filer 1990, I997; Ashley and Haysom 2006; Kirsch 2006; West 2006; Kepore and Imbun 20II; Banks and others 2013; Coles, Fenclova, and Dinan 20I3; Koutra 20I3; Golub 20I4; Bradly 20I5; Jacka 20I5; Banks and others 20I6; Hughes 20I6; Kuir-Ayius 2016.

2 The 2006 Happy Planet Index, however, did include Pacific Island nations, with Vanuatu ranked as the happiest country, and Island nations in general ranking highly (New Economics Foundation 2006, 3, 30).

3 The research program was led by Professors Regina Scheyvens and Glenn Banks at the Institute of Development Studies, Massey University, and funded by the Royal Society of New Zealand from 2013 to 2016. 
4 "Kastom" is a Tok Pisin term that is akin to the terms "ritual" (Gillespie 2013) or "tradition" (Otto and Pedersen 2005).

5 There is some effort by intermediary organizations to bridge the disconnection between company and community priorities, for example, the Fiji-based nongovernmental organization Rise Beyond the Reef (Hughes 2016, I93-I95).

\section{References}

Ashley, Caroline, and Gareth Haysom

2006 From Philanthropy to a Different Way of Doing Business: Strategies and Challenges in Integrating Pro-Poor Approaches into Tourism Business. Development Southern Africa 23: 265-280.

Atkinson, Sarah, Sara Fuller, and Joe Painter

$20 \mathrm{I} 2$ Wellbeing and Place. In Wellbeing and Place, edited by Sarah Atkinson, Sara Fuller, and Joe Painter, I-I4. Surrey, Uk: Ashgate Publishing.

Bainton, Nicholas A

2009 Keeping the Network Out of View: Mining, Distinctions and Exclusion in Melanesia. Oceania 79 (I): I 8-33.

2010 The Libir Destiny: Cultural Responses to Mining in Melanesia. Canberra: ANU Press.

Banks, Glenn, Dora Kuir-Ayius, David Kombako, and Bill Sagir

20I3 Conceptualizing Mining Impacts, Livelihoods and Corporate Community Development in Melanesia. Community Development Journal 48 (3): 484-500.

Banks, Glenn, Regina Scheyvens, Sharon McLennan, and Anthony Bebbington 20I6 Conceptualising Corporate Community Development. Third World

Barker, John Quarterly 37 (2): 245-263.

2007 Introduction: The Anthropological Study of Morality in Melanesia. In The Anthropology of Morality in Melanesia and Beyond, edited by John Barker, I-24. Hampshire, UK: Ashgate Publishing.

Bernard, Karen, and Samantha Cook

2015 Luxury Tourism Investment and Flood Risk: Case Study on Unsustainable Development in Denarau Island Resort in Fiji. International Journal of Disaster Risk Reduction I4:302-3 I I.

Bradly, Andrew

2015 The Business-Case for Community Investment: Evidence from Fiji's Tourism Industry. Social Responsibility Journal I I (2): 242-257.

Chambers, Robert

I997 Editorial: Responsible Well-Being-A Personal Agenda for Development. World Development 25 (I I): I743-I754. 
Coles, Tim, Emily Fenclova, and Claire Dinan

2013 Tourism and Corporate Social Responsibility: A Critical Review and Research Agenda. Tourism Management Perspectives 6: I 22-I4I.

Copestake, James

2008 Wellbeing in International Development: What's New? Journal of International Development 20 (5): 577-597.

Cox, James

2006 Gutpela Tingting na Sindaun: Papua New Guinean Perspectives on a Good Life. Discussion paper, June. Burwood East, vic: World Vision Australia Advocacy and Public Influence Unit.

Deneulin, Séverine

$20 \mathrm{I}$ Wellbeing, Justice and Development Ethics. London: Routledge.

Epler Wood, Megan, and Thais Leray

2005 Corporate Responsibility and the Tourism Sector in Cambodia. Washington, DC: World Bank Group.

Ernst \& Young Australia

2017 Papua New Guinea Extractive Industries Transparency Initiative Report 20I4. Second PNG Extractive Industries Transparency Initiative (EITI) report, 24 Feb. Ernst \& Young Australia. https://eiti.org/ sites/default/files/documents/papua_new_guinea_eiti_report_2OI 4

Eweje, Gabriel .pdf [accessed 20 April 20I8]

2007 Multinational Oil Companies' CSR Initiatives in Nigeria: The Scepticism of Stakeholders in Host Communities. Managerial Law 49 (5/6): $218-235$.

Filer, Colin

I990 The Bougainville Rebellion, the Mining Industry and the Process of Social Disintegration in Papua New Guinea. Canberra Anthropology I3 (I): I-39.

I997 Compensation, Rent and Power in Papua New Guinea. In Compensation for Resource Development in Papua New Guinea, edited by Susan Toft, I 56-I89. Boroko, NCD: Law Reform Commission of Papua New Guinea; Canberra: Resource Management in Asia and the Pacific, Research School of Pacific and Asian Studies, and the National Centre for Development Studies, The Australian National University.

Fischer, Edward F

2014 The Good Life: Aspiration, Dignity, and the Anthropology of Wellbeing. Stanford: Stanford University Press.

Gasper, Des

2007 Conceptualising Human Needs and Wellbeing. In Wellbeing in Developing Countries: From Theory to Research, edited by Ian Gough and 
J Allister McGregor, 47-70. Cambridge, Uk: Cambridge University Press.

Gasper, Des, and Asuncion Lera St Clair, editors

2016 Development Ethics. London: Ashgate Publishing.

Gegeo, David W

I998 Indigenous Knowledge and Empowerment: Rural Development

Gillespie, Kirsty

Examined from Within. The Contemporary Pacific Io (2): 289-3 I 5.

2013 Ethnomusicology and the Mining Industry: A Case Study from Lihir, Papua New Guinea. Musicology Australia 35 (2): I78-I90.

Golub, Alex

2014 Leviathans at the Gold Mine: Creating Indigenous and Corporate Actors in Papua New Guinea. Durham, NC: Duke University Press.

Gough, Ian, J Allister McGregor, and Laura Camfield

2007 Theorising Wellbeing in International Development. In Wellbeing in Developing Countries: From Theory to Research, edited by Ian Gough and J Allister McGregor, 3-44. Cambridge: Cambridge University Press.

Hau'ofa, Epeli

I994 Our Sea of Islands. The Contemporary Pacific 6 (I):I48-I6I.

Helliwell, John, Richard Layard, and Jeffrey Sachs, editors

2012 World Happiness Report. New York: The Earth Institute, Columbia University.

Huffer, Elise, and Ropate Qalo

2004 Have We Been Thinking Upside-Down? The Contemporary Emergence of Pacific Theoretical Thought. The Contemporary Pacific I 6 (I):87-I I 6 .

Hughes, Emma Louise

2016 The Tourist Resort and the Village: Local Perspectives of Corporate Community Development in Fiji. PhD thesis, Development Studies, Massey University, New Zealand.

Hughes, Emma, and Regina Scheyvens

2016 Corporate Social Responsibility in Tourism Post-2015: A Development First Approach. Tourism Geographies I 8 (5): 469-482.

Jacka, Jerry K

2007 Whitemen, the Ipili, and the City of Gold: A History of the Politics of Race and Development in Highlands New Guinea. Ethnohistory $54(3): 445-472$.

2015 Alchemy in the Rain Forest: Politics, Ecology, and Resilience in a New Guinea Mining Area. Durham, NC: Duke University Press.

Jiménez, Alberto Corsín

2008 Introduction: Well-Being's Re-Proportioning of Social Thought. In 
Culture and Well-Being: Anthropological Approaches to Freedom and Political Ethics, edited by Alberto Corsín Jiménez, I-34. London: Pluto Press.

Kabutaulaka, Tarcisius

20I5 Re-Presenting Melanesia: Ignoble Savages and Melanesian AlterNatives. The Contemporary Pacific 27 (I): I IO-I 45.

Kalisch, Angela

2002 Corporate Futures: Social Responsibility in the Tourism Industry. Consultation on Good Practice paper. London: Tourism Concern.

Kapelus, Paul

2002 Mining, Corporate Social Responsibility and the "Community": The Case of Rio Tinto, Richards Bay Minerals and the Mbonambi. Journal of Business Ethics 39 (3): 275-296.

Kepore, Kevin P, and Benedict Y Imbun

20I I Mining and Stakeholder Engagement Discourse in a Papua New Guinea Mine. Corporate Social Responsibility and Environmental Management I 8 (4): 220-233.

Kero, Robin Kewai

I998 Nominalism in Papua New Guinea. Melanesian Journal of Theology I4 (I): $57-88$.

Kirsch, Stuart

2006 Reverse Anthropology: Indigenous Analysis of Social and Environmental Relations in New Guinea. Stanford: Stanford University Press.

Koutra, Christina

2013 More Than Simply Corporate Social Responsibility: Implications of Corporate Social Responsibility for Tourism Development and Poverty Reduction in Developing Countries; A Political Economy Perspective. New York: Nova Science.

Kuir-Ayius, Dora Dau

2016 Building Community Resilience in Mine Impacted Communities: A Study on Delivery of Health Services in Papua New Guinea. PhD thesis, Development Studies, Massey University, New Zealand.

McGregor, Davianna Pōmaika'i, Paula Tanemura Morelli, Jon Kei Matsuoka, and Luciano Minerbi

2003 An Ecological Model of Well-Being. In The International Handbook of Social Impact Assessment: Conceptual and Methodological Advances, edited by Henk A Becker and Frank Vanclay, Io9-I 26. Cheltenham, uk: Edward Elgar.

McGregor, J Allister

2007 Researching Wellbeing: From Concepts to Methodology. In Wellbeing in Developing Countries: From Theory to Research, edited by Ian 
Gough and J Allister McGregor, 316-350. Cambridge: Cambridge University Press.

Meo-Sewabu, Litea

2015 "Tu ga na inima ka luvu na waqa" (The bail to get water out of the boat is in the boat yet the boat sinks): The Cultural Constructs of Health and Wellbeing amongst Marama iTaukei in a Fijian Village in Lau and in a Transnational Fijian Community in Whanganui, Aotearoa. PhD thesis, Social Policy, Massey University, New Zealand.

Meo-Sewabu, Litea, and Wheturangi Walsh-Tapiata

2012 Global Declaration and Village Discourses: Social Policy and Indigenous Wellbeing. AlterNative: An International Journal of Indigenous Peoples 8 (3): 305-3 I7.

Mila-Schaaf, Karlo, and Maui Hudson

2009 The Interface between Cultural Understandings: Negotiating New Spaces for Pacific Mental Health. Pacific Health Dialog I 5 (I) II3II9.

Moore, Sean E, Heather Young-Leslie, and Carrie A Lavis

2005 Subjective Well-Being and Life Satisfaction in the Kingdom of Tonga. Social Indicators Research 70 (3): 287-3 I I.

Movono, Apisalome, Stephen Pratt, and David Harrison

2015 Adapting and Reacting to Tourism Development: A Tale of Two Villages on Fiji's Coral Coast. In Tourism in Pacific Islands: Current Issues and Future Challenges edited by Stephen Pratt and David Harrison, IOI-II7. Volume 48, Contemporary Geographies of Leisure, Tourism and Mobility. Oxford, uk: Routledge.

Nabobo-Baba, Unaisi

2006 Knowing and Learning: An Indigenous Fijian Approach. Suva: Institute of Pacific Studies.

2015 The Mutual Implication of Kinship and Chiefship in Fiji. In Living Kinship in the Pacific, edited by Christina Toren and Simone Pauwels, I 5-35. New York: Berghahn Books.

New Economics Foundation

2006 The (un)Happy Planet Index: An Index of Human Well-Being and Environmental Impact. London: New Economics Foundation.

Newcrest Mining Limited

2015 Lihir, Papua New Guinea. Two-page flyer, October. http://www .newcrest.com.au/media/our_business/4365_Newcrest_FS_Lihir _October20I5_LR.pdf [accessed 6 April 20I8]

Orathinkal, Jose, and Alfons Vansteenwegen

2004 Towards Developing a Family Therapy for Melanesia. Australian and New Zealand Journal of Family Therapy 25 (3): I48-I 54. 
Otto, Ton, and Poul Pedersen

2005 Disentangling Traditions: Culture, Agency and Power. In Tradition and Agency: Tracing Cultural Continuity and Invention, edited by Ton Otto and Poul Pedersen, I I-49. Aarhus, DK: Aarhus University Press.

Pratt, Stephen, Scott McCabe, and Apisalome Movono

2016 Gross Happiness of a "Tourism" Village in Fiji. Journal of Destination Marketing and Management 5 (I): 26-35.

Radcliffe, Sarah A

2012 Development for a Postneoliberal Era? Sumak Kawsay, Living Well and the Limits to Decolonisation in Ecuador. Geoforum 43 (2): 240249.

Ratuva, Steven

2010 Back to Basics: Towards Integrated Social Protection for Vulnerable Groups in Vanuatu. Pacific Economic Bulletin 25 (3): 40-63.

Scheyvens, Regina, Glenn Banks, and Emma Hughes

2016 The Private Sector and the SDgs: The Need to Move Beyond "Business as Usual." Sustainable Development 24 (6): 37 I-382.

Spann, Michael

20I 8 "Living Other-Wise": The Bushmen Farming Network as an Example of "Alter-Native" Counter Practices to Agriculture and Development. The Contemporary Pacific 30 (I): 33-68.

St Barbara Limited

2015 Annual Report 20I5. https://stbarbara.com.au/wp-content/uploads/ 20I8/03/st_barbara_limited_annual_report_20I5.pdf [accessed 6 April 20I8]

Stewart, Pamela J, and Andrew Strathern

2000 Introduction: Latencies and Realizations in Millennial Practices. Ethnobistory 47 (I): 3-27.

Telfer, David J, and Richard Sharpley

2008 Tourism and Development in the Developing World. Abington, UK: Routledge.

Tuwere, Ilaitia S

2002 Vanua: Towards a Fijian Theology of Place. Suva: University of the South Pacific; Auckland: College of St John the Evangelist.

UNDP, United Nations Development Programme

I990 Human Development Report 1990. New York: Oxford University Press. http://hdr.undp.org/en/reports/global/hdri 990 [accessed 2 May 20I 8]

UNGA, United Nations General Assembly

20I I Happiness: Towards a Holistic Approach to Development. Resolu- 
tion adopted by the General Assembly on I9 July, sixty-fifth session, agenda item I3, A/RES/65/309.

2015 Transforming Our World: The 2030 Agenda for Sustainable Development. https://sustainabledevelopment.un.org/post20 I 5/transforming ourworld [accessed 30 April 20I8]

Veenhoven, Ruut

2015 World Database of Happiness. In Encyclopedia of Quality of Life and Well-Being Research. Rotterdam, NL: Erasmus University. http:// worlddatabaseofhappiness.eur.nl [accessed 30 April 20I 8]

Wani, Gibson

2010 Fear and Traditional Beliefs in Papua New Guinea: Personal Reflections. Melanesian Journal of Theology 26 (2): 88-92.

Weber-Fahr, M

2002 Treasure or Trouble? Mining in Developing Countries. Washington, DC: World Bank Group.

West, Paige

2006 Environmental Conservation and Mining: Strange Bedfellows in the Eastern Highlands of Papua New Guinea. The Contemporary Pacific I 8 (2): 295-3 I 3 .

White, Sarah C

2009 Bringing Wellbeing into Development Practice. Wellbeing in Developing Countries (WeD) Working Paper 09/50. Bath, Uk: University of Bath and Wellbeing in Developing Countries Research Group.

20I4 Practical Choices in Designing a Wellbeing and Quality of Life Assessment. In Wellbeing and Quality of Life Assessment: A Practical Guide, edited by Sarah C White, 25-36. Rugby, Warwickshire, Uк: Practical Action Publishing.

2016 Introduction: The Many Faces of Wellbeing. In Cultures of Wellbeing: Method, Place, Policy, edited by Sarah C White and Chloe Blackmore, I-44. Basingstoke, UK: Palgrave Macmillan.

World Bank

2009 World Bank Oil, Gas and Mining Policy Division. Brochure, August.

Washington, DC: World Bank. http://siteresources.worldbank.org/ EXTOGMC/Resources/COCPObrochureFINAL.pdf?resourceurl name=COCPObrochureFINAL.pdf [accessed 3 I July 20I 8]

20I3 Oil, Gas, and Mining Unit. http://web.worldbank.org/WBSITE/ EXTERNAL/TOPICS/EXTOGMC/o,,menuPK:336936 pagePK :I 490 I 8 piPK:I 49093 theSitePK:336930,00.html [accessed 2I April 20I7]

World Travel and Tourism Council

2017 Travel and Tourism: Economic Impact 2017; Fiji. London: World 
Travel and Tourism Council. https://www.wttc.org/-/media/files/ reports/economic-impact-research/countries-20I //fiji20I 7.pdf [accessed 2I April 2017]

\section{Abstract}

This article examines examples of indigenous conceptions of well-being and locally meaningful forms of community development in the Pacific and considers how these coincide, or collide, with development driven by the private sector. The focus is on indigenous communities who live in the vicinity of large multinational corporations, using case studies from Papua New Guinea and Fiji. We investigate how communities' perceptions of well-being intersect with the concept of development as it emanates from the private sector. In order to do this, we explore how communities perceive well-being, what materializes as being significant to its achievement, and what this means in the presence of international capital. Ultimately the purpose of investigating these concepts is to establish a point of reference for considering the effectiveness and value of corporate community development intervention from a community perspective.

KEYWORDS: well-being, community development, mining, tourism, the good life, Fiji, Papua New Guinea 